\title{
Herbal compound triptolide synergistically enhanced antitumor activity of amino-terminal fragment of urokinase
}

\author{
Yuli Lin ${ }^{1}$, Nana Peng ${ }^{1}$, Jianping Li ${ }^{1}$, Hongqin Zhuang ${ }^{1,2,3^{*}}$ and Zi-Chun Hua ${ }^{1,2,3^{*}}$
}

\begin{abstract}
Background: Urokinase (UPA) and its receptor (UPAR) play an important role in tumour growth and metastasis, and overexpression of these molecules is strongly correlated with poor prognosis in a variety of malignant tumours. Targeting the excessive activation of this system as well as the proliferation of the tumour vascular endothelial cell would be expected to prevent tumour neovasculature and halt tumour development. The amino terminal fragment (ATF) of urokinase has been confirmed effective to inhibit the proliferation, migration and invasiveness of cancer cells via interrupting the interaction of UPA and UPAR. Triptolide (TPL) is a purified diterpenoid isolated from the Chinese herb Tripterygium wilfordii Hook F that has shown antitumor activities in various cancer cell types. However, its therapeutic application is limited by its toxicity in normal tissues and complications caused in patients. In this study, we attempted to investigate the synergistic anticancer activity of TPL and ATF in various solid tumour cells.
\end{abstract}

Methods: Using in vitro and in vivo experiments, we investigated the combined effect of TPL and ATF at a low dosage on cell proliferation, cell apoptosis, cell cycle distribution, cell migration, signalling pathways, xenograft tumour growth and angiogenesis.

Results: Our data showed that the sensitivity of a combined therapy using TPL and ATF was higher than that of TPL or ATF alone. Suppression of NF-KB transcriptional activity, activation of caspase-9/caspase-3, cell cycle arrest, and inhibition of UPAR-mediated signalling pathway contributed to the synergistic effects of this combination therapy. Furthermore, using a mouse xenograft model, we demonstrated that the combined treatment completely suppressed tumour growth by inhibiting angiogenesis as compared with ATF or TPL treatment alone.

Conclusions: Our study suggests that lower concentration of ATF and TPL used in combination may produce a synergistic anticancer efficacy that warrants further investigation for its potential clinical applications.

Keywords: Amino-terminal fragment of urokinase, Triptolide, Synergism, Apoptosis, Cell migration, Cell cycle, Xenograft

\section{Background}

Various proteolytic enzymes play important roles in tumour invasion and metastasis process. These proteases involve cathepsins, collagenases, plasmin, or plasminogen activators [1]. Urokinase-type plasminogen activator (uPA) and its receptor, uPAR, are important components of cell surface proteolysis used by tumour cells and

\footnotetext{
* Correspondence: hqzhuang@nju.edu.cn; hzc1117@nju.edu.cn

${ }^{1}$ The State Key Laboratory of Pharmaceutical Biotechnology, College of Life Science, Nanjing University, 22 Han Kou Road, Nanjing 210093, PR China ${ }^{2}$ Changzhou High-Tech Research Institute of Nanjing University, Changzhou 213164, Jiangsu, PR China

Full list of author information is available at the end of the article
}

capillary endothelial cells, and therefore play crucial roles in the establishment, metastasis and angiogenesis of most solid tumours [2,3]. UPA and UPAR are overexpressed in diverse human malignant tumours in contrast to the corresponding normal tissue [4]. There are several potential mechanisms underlying the promotion of UPA and UPAR to tumour growth and invasion. Firstly, binding of uPA to uPAR leads to activation of plasminogen to plasmin, and the plasmin in turn activates latent matrix metalloproteases (MMPs) to dissolve the components of extracellular matrix (ECM) and the basement membrane $[5,6]$. Secondly, the binding of uPA

\section{Biomed Central}

(c) 2013 Lin et al.; licensee BioMed Central Ltd. This is an Open Access article distributed under the terms of the Creative Commons Attribution License (http://creativecommons.org/licenses/by/2.0), which permits unrestricted use, distribution, and reproduction in any medium, provided the original work is properly cited. 
and UPAR can also activate multiple cell signalling molecules via some growth factor receptors, such as integrins and EGFR, and then stimulate cell mobility and growth $[7,8]$. Finally, uPA-uPAR system is implicated in tumourassociated angiogenesis $[9,10]$. All these crucial roles of uPA-uPAR system in tumour growth and metastasis make it an ideal candidate for targeted cancer therapy. Therapeutic molecules aimed at interrupting the interaction of UPA and UPAR may inhibit both tumour cell invasiveness and tumour-associated angiogenesis, thereby might be effective in cancer therapy. For example, the monoclonal antibody against uPA or UPAR has been confirmed effective to inhibit the proliferation, migration and invasiveness of cancer cells in vitro $[11,12]$. Another known antagonist inhibitor of uPAUPAR is ATF, the amino-terminal fragment of urokinase which harbours an epidermal growth factor (EGF)-like domain and a kringle domain. ATF could efficiently inhibit angiogenesis and tumour invasion in vitro and in vivo by competing with uPA for binding to both endothelial and tumour cell surfaces [13-15].

The Chinese herb Tripterygium wilfordii Hook F (TWHF) has been used for centuries in the treatment of rheumatoid arthritis and several other autoimmune and inflammatory diseases [16-18]. Triptolide (TPL; $\mathrm{C}_{20} \mathrm{H}_{24} \mathrm{O}_{6}$ ), a diterpenoid triepoxide, is purified from TWHF, which has been found to possess potent immunosuppressive and anti-inflammatory properties [19]. The antitumor activity of TPL was first reported 40 years ago, when it was observed to induce cell apoptosis in leukaemia. TPL has since attracted much research interest [20]. TPL has been observed to inhibit the proliferation of several types of cancer cells in vitro and to reduce the growth and metastasis of tumours in vivo [21]. Results from in vivo studies indicate that TPL inhibits tumour xenografts in nude mice from several human cancer cell lines, including melanoma, bladder cancer, breast cancer, and gastric and colorectal carcinoma [22,23]. Not only can TPL inhibit tumour growth directly in vitro and in vivo but it can also be efficacious as an adjunct agent for enhancing the antitumor effects of chemotherapeutic or other cytotoxic agents [24-26]. However, the therapeutic potential of TPL is still limited due to its strong toxicity $[27,28]$.

The combined inhibitory effects of TPL and other anticancer drugs on tumour cell growth were reported to be superior to the effects of these agents used singly [24,29]. Considering the antitumor activity of both ATF and TPL, we therefore hypothesized that the combination of TPL and ATF would enhance apoptosis in human solid tumour cells. The results presented in this study demonstrate that TPL and ATF combined treatment synergistically induces apoptosis in several human solid tumour cell lines through caspase-dependent pathway. In addition, combination of TPL and ATF at a low dosage eliminates the cytotoxicity of normal cells induced by the individual drugs at their effective concentrations. The combined treatment of TPL and ATF also show robust in vivo efficacy, which strongly suggests that TPL has potential in modulating and enhancing the apoptosis and anti-angiogenesis induced by ATF on human solid tumour cells, especially colon cancer, and the synergistic effects of their combination point to a more promising modality for treating colon cancer.

\section{Results}

\section{ATF expression and purification}

The Pichia expression system was used to prepare ATF in soluble form. After ammonium sulphate precipitation, the target protein was concentrated in a small buffer volume and significant removal of some contaminants was achieved. In the ion exchange purification step, ATF was eluted as a single homogenous peak at $0.2 \mathrm{M} \mathrm{NaCl}$. After the final step, the desired level of product purity (> 98\%) was achieved. The final yield was about $18 \mathrm{mg} / \mathrm{L}$ culture. On SDS-PAGE, the mobility of the purified protein was found to correspond to a molecular weight of about $15 \mathrm{kDa}$ (Figure 1A). The purified protein was further examined by Western blotting using anti-human ATF antibody. As shown in Figure 1B, the ATF migrated at $15 \mathrm{kDa}$ as expected and no degradation was observed.

\section{Effect of single drug exposure on the growth of human HCT116 colon cancer cell line and A549 lung adenocarcinoma cell line}

The inhibition of proliferation by TPL and ATF of the human HCT116 colon cancer cell line and A549 lung adenocarcinoma cell line was assessed after $24 \mathrm{~h}$ of drug exposure, following $24 \mathrm{~h}$ culture in drug-free medium. As shown in Figure 2A, growth of the HCT116 and A549 cells was significantly inhibited in a dosedependent manner in vitro $(p<0.05)$ by either drug treatment alone. For HCT116 cells, the inhibition ratio

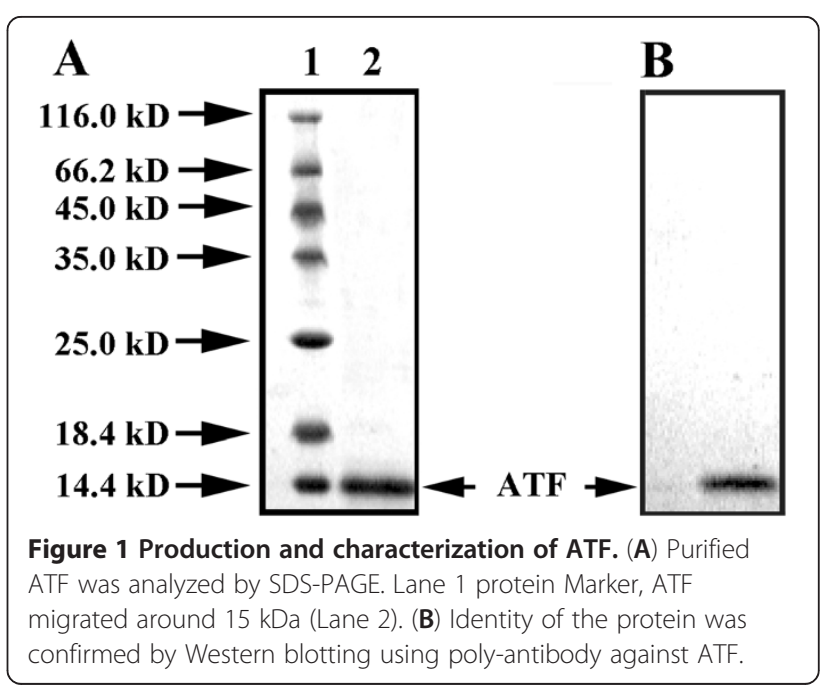



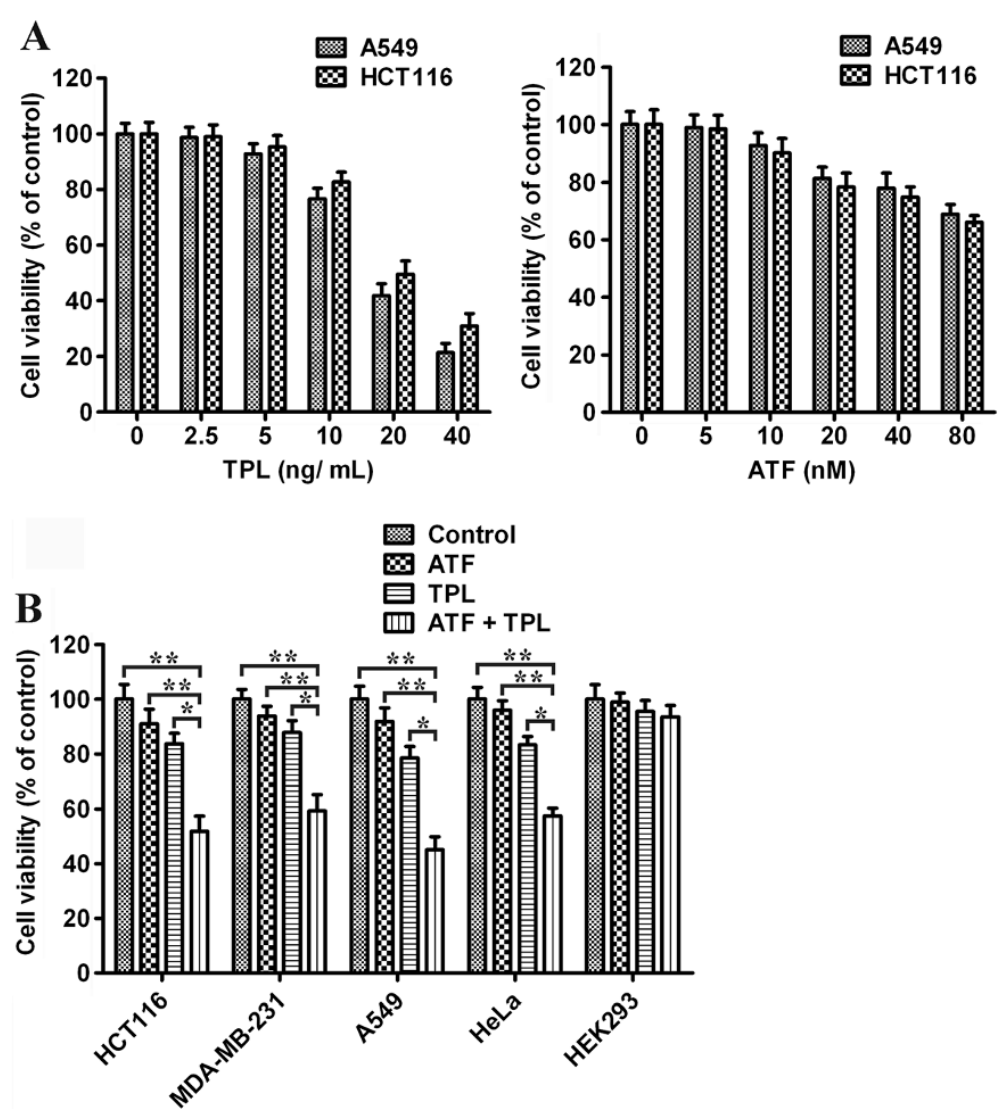

Figure 2 Effect of TPL and ATF on the growth of tumour cells in vitro. (A) Left, A549 and HCT116 Cells were treated with TPL at different concentrations $(0,2.5,5,10,20,40 \mathrm{ng} / \mathrm{mL})$ for $24 \mathrm{~h}$, and the cell viability was assessed by MTT assay. Right, A549 and HCT1 16 cells were treated with ATF at different concentrations (0, 5, 10, 20, 40, $80 \mathrm{nM}$ ) for $24 \mathrm{~h}$, and the cell viability was assessed by MTT assay. (B) Combined effects of TPL and ATF on growth of HCT116, MDA-MB-231, A549, HeLa, and HEK293 cells. HCT116, MDA-MB-231, A549, HeLa, and HEK293 cells were exposed to TPL $(10 \mathrm{ng} / \mathrm{mL})$ and/or ATF $(10 \mathrm{nM})$ for $24 \mathrm{~h}$. Combined treatment resulted in significant growth inhibition of tumour cells, more than that by either drug alone; the degree of cytotoxicity in normal cells was not significant. Each bar shows the mean \pm SD of three independent experiments, performed in triplicate. ${ }^{*} p<0.05,{ }^{* *} p<0.01$.

was $1.2 \pm 0.24 \%$ at the concentration of $2.5 \mathrm{ng} / \mathrm{mL}$ of TPL, and $69.2 \pm 1.65 \%$ at the concentration of $40 \mathrm{ng} / \mathrm{mL}$. ATF at $5 \mathrm{nM}$ had an inhibition ratio of $1.5 \pm 0.42 \%$, while the ratio was $34.2 \pm 1.32 \%$ at $80 \mathrm{nM}$. In this study, we used the concentration at which ATF did not induce proliferation inhibition on its own. Therefore, in the subsequent combined treatment we choose ATF at the concentration of $10 \mathrm{nM}$ and TPL at a low dosage of $10 \mathrm{ng} / \mathrm{mL}$.

\section{Combined effect of TPL and ATF on growth of tumour cells}

In order to assess the combined effect of TPL and ATF on tumour cell proliferation, MTT assay was performed. Four solid tumour cell lines and a normal cell line were treated with ATF $(10 \mathrm{nM})$, TPL $(10 \mathrm{ng} / \mathrm{mL})$ or the combination for 24 hours. As shown in Figure 2B, ATF treatment alone did not cause obvious growth inhibition in all cell lines. TPL treatment alone induced 15-20\% inhibition ratio, however, addition of ATF led to a significant increase in inhibition ratio (40-50\%) as compared to TPL alone $(p<0.05)$ and to ATF alone $(p<$ $0.01)$ in tumour cell lines. The combination index (CI) was 0.681 for HCT116 cells, 0.721 for MDA-MB-231 cells, 0.625 for A549 cells, and 0.721 for HeLa cells, indicating their synergistic effect on inhibiting the proliferation of tumour cells at lower concentrations. In contrast, no synergistic cytotoxicity was observed in HEK293 cells. These results showed that TPL at a subtoxic concentration had an enhanced effect on ATF-inhibited proliferation of tumour cells without increasing cytotoxicity to normal cells.

Combined effect of TPL and ATF on tumour cell apoptosis To determine whether tumour cellular viability decreased with TPL and ATF via apoptosis, we measured the externalization of phosphatidylserine on the cell membrane using Annexin V/PI staining. Two 
different solid tumour cell lines (HCT116 and A549) were exposed to ATF $(10 \mathrm{nM})$, TPL $(10 \mathrm{ng} / \mathrm{mL})$ or a combination of both (ATF $10 \mathrm{nM}+$ TPL $10 \mathrm{ng} / \mathrm{mL}$ ). As shown in Figure 3A, after $24 \mathrm{~h}$ of treatment, ATF alone had no obvious effect on tumour cell apoptosis, while single therapy with TPL induced $15-25 \%$ apoptosis ratio. However, when HCT116 and A549 cells were exposed to combined therapy with TPL and ATF, the number of cells undergoing apoptosis significantly increased (55-65\%). This effect was statistically significant as compared to single therapy with either drug alone.

\section{Regulatory mechanisms of TPL and ATF-induced apoptosis in HCT116 cells}

To explore the mechanisms of TPL and ATF-induced apoptosis in HCT116 cells, activation of caspases and expression of pro-apoptotic proteins were analyzed by Western blotting assay. Caspases are the main enzymes that mediate apoptosis. Any stimuli that triggers apoptosis eventually leads to the activation of the effector caspases, including caspase- 3 , caspase- 6 , and caspase- 7 . In cells treated for $24 \mathrm{~h}$, only the combined treatment with TPL and ATF significantly enhanced the cleavage of procaspase-3 and the downstream PARP, while treatment with TPL or ATF alone caused minimal proteolytic processing of procaspase- 3 and cleavage of PARP. In addition, combined treatment of HCT116 cells with TPL and ATF noticeably increased the levels of BAX, BAK and BAD with a prominent reduction of cIAP level (Figure 3B). Caspase activity, shown in Figure 3C, indicated that caspase- 3 and caspase- 9 activities were elevated to 1.6- and 1.3-fold over controls in cells treated with ATF and 8.5- and 4.7-fold over that in combined
A A549
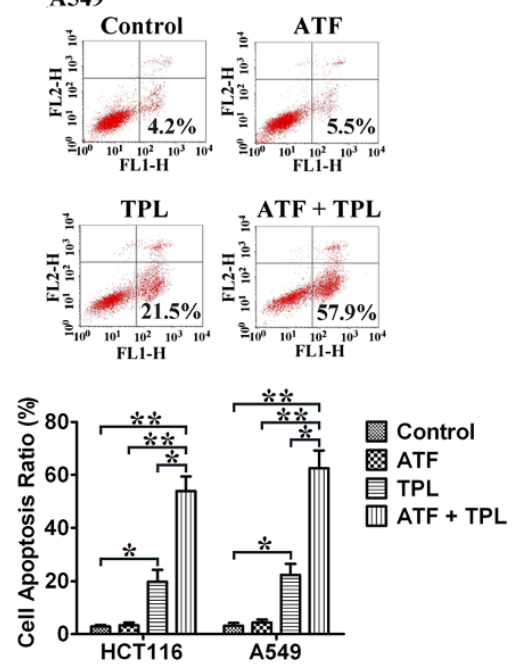

C

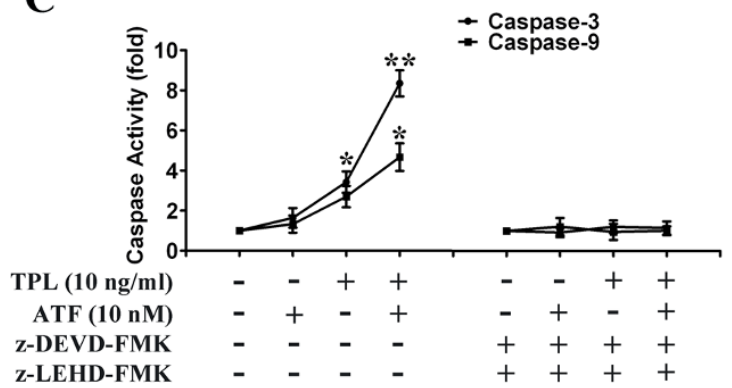

B

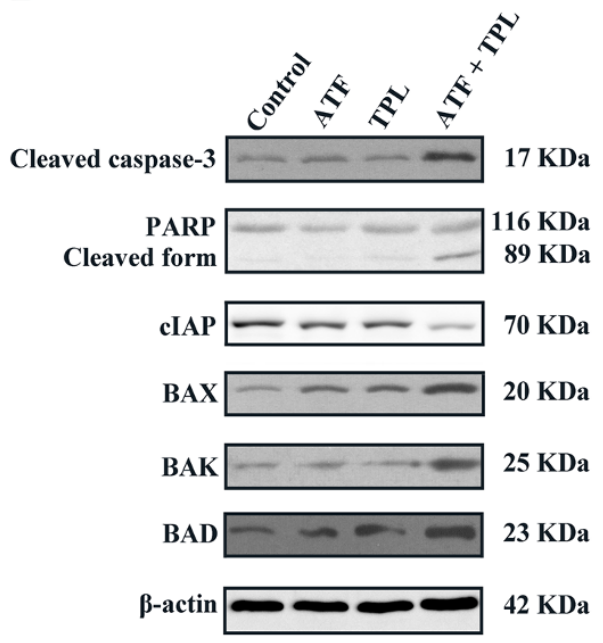

D

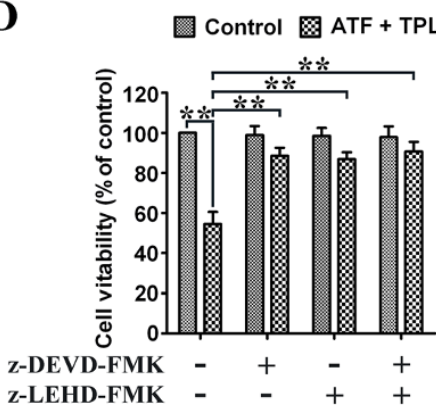

Figure 3 Effects of TPL and ATF on tumour cell apoptosis and caspase activation. (A) A549 and HCT116 cells were exposed to TPL (10 ng/mL) and/or ATF (10 nM). Twenty-four hours later, all cells were harvested for flow cytometry analysis. Annexin V/PI-stained cells were analyzed with the percentages of apoptosis cells. The experiments were carried out independently in triplicate; representative data are shown. ${ }^{*} p<0.05,{ }^{* *} p<0.01$. Annexin V/PI double staining profile of A549 cells is also included. (B) Cleaved caspase-3, PARP, CIAP, BAX, BAD, and BAK expressions in HCT116 cells under different treatment conditions. (C) Activity of caspase-3 and caspase-9 in HCT116 cells treated with TPL and ATF alone or in combination for 24 h. Data are presented as fold increases as determined by quantitative analysis. (D) Viability of HCT116 cells after treatment with caspase inhibitors. Cells were treated with inhibitors for $2 \mathrm{~h}$ before the $24 \mathrm{~h}$ treatments, after which cell viability was determined by MTT assay. Data are representative of three independent experiments. ${ }^{*} p<0.05,{ }^{* *} p<0.01$. 
treatment, respectively. Co-treatment with the caspase inhibitors z-DEVD-FMK and z-LEHD-FMK abolished caspase activation induced by TPL and ATF and rescued HCT116 cells from treatment-induced cell death (Figure 3C and 3D). Cell viability was also increased by caspase inhibitors after combined treatment. These findings indicate that activation of a caspase-involved apoptotic pathway is one of the major mechanisms via which TPL exerts its synergistic effect on ATF-treated HCT116 cells.

The cooperation of TPL with chemotherapy and cytokines to induce apoptosis in cell lines has been attributed to inhibition of the NF-kB pathway [30]. Thus, we investigated whether TPL at the dosage of $10 \mathrm{ng} / \mathrm{mL}$ was able to modify the rate of NF- $\mathrm{kB}$ inhibition. Low dosage of ATF or TPL alone had no obvious effect on the expression of NF- $\mathrm{B} / \mathrm{p} 65$. However combined treatment decreased the level of NF- $\mathrm{KB} / \mathrm{p} 65$ in the nucleus of HCT116 cells co-treated for $24 \mathrm{~h}$ (Figure 4A). c-FLIP, one of the targeted genes of NF-kB, is known to interfere with caspase activation downstream of death receptors. To evaluate the combined effect of ATF and TPL on c-FLIP expression, we treated HCT116 cells with ATF in the absence or the presence of TPL. Our Western blotting assay showed that combined treatment decreased c-FLIP expression, while ATF or TPL alone had no effect on c-FLIP expression (Figure 4B). To further determine whether NF- $\mathrm{KB}$ inhibition resulted in reduction of c-FLIP, HCT116 cells were transfected with NF- $\mathrm{kB}$ p65 siRNA. Western blotting analysis revealed that siRNA against NF- $\mathrm{kB}$ p65 effectively reduced NF$\mathrm{kB} / \mathrm{p} 65$ and c-FLIP-L levels in the transfected cells (Figure 4C). AKT was reported to suppress apoptosis by stimulating the transactivation potential of the RelA/p65 subunit of NF-kB [31,32]. Therefore, the detection of Ser473 p-AKT and total AKT in HCT116 cells was performed following exposure to TPL and ATF for $24 \mathrm{~h}$. Figure $4 \mathrm{~B}$ revealed that the phosphorylation level of AKT was markedly decreased after co-treatment with TPL and ATF, but not either drug alone. JNK is known to promote apoptosis by many cellular stresses, including oxidative stresses, and DNA-damaging agents [33] and plays important roles in cell proliferation and apoptosis [34]. We hypothesized that JNK might be activated by cellular stress induced by TPL and ATF combined treatment. As expected, the level of phospho-JNK increased in cells co-treated with TPL and ATF. Furthermore, the combination of TPL and ATF induced a slight increase in the level of phospho-c-JUN in HCT116 cells (Figure 4D). In contrast, low dosage of ATF or TPL alone failed to activate the JNK-c-JUN pathway. Taken together, these findings suggest that TPL and ATF cooperatively induce apoptosis through the suppression of $\mathrm{NF}-\kappa \mathrm{B}$ transcriptional activity, subsequently reduction of

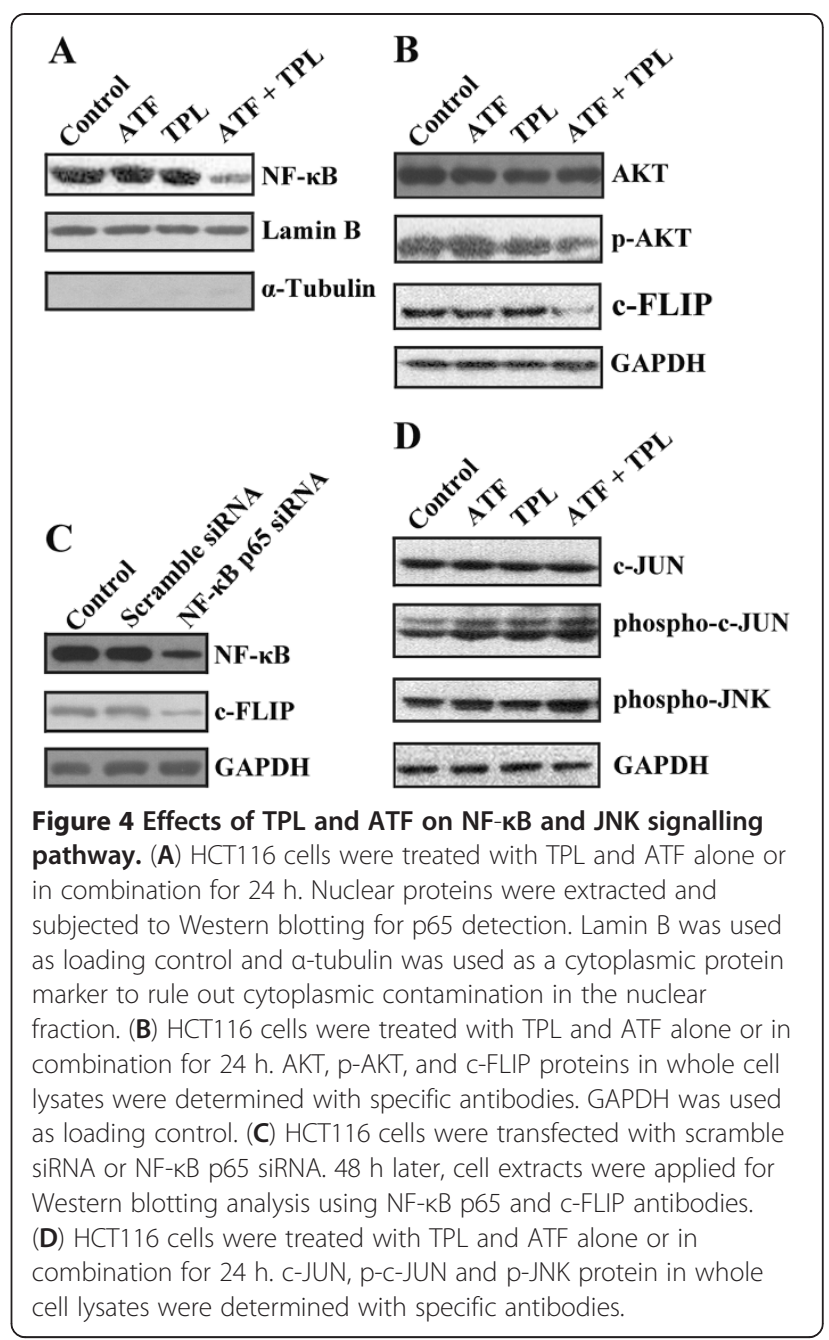

c-FLIP expression, and activation of caspases-9/caspase3 and the JNK-c-JUN pathway.

\section{TPL and ATF combined therapy initiated cell cycle arrest at $\mathrm{S}$ phase in HCT116 cells}

TPL has been reported to have the ability of inhibiting cell proliferation to execute its antitumor effect. Thus, we detected the effect of ATF, TPL or the combination on cell cycle distribution. As shown in Figure 5, ATF treatment alone had no effect on cell cycle distribution. However, when cells were incubated with TPL, the cell population of G0/G1 phase decreased from $55.3 \%$ to $29.8 \%$ and S phase increased from $10.3 \%$ to $41.2 \%$. When combined with ATF, the cell population of S phase was similar to TPL treatment alone with the ratio of $40.5 \%$, and the cell population of $\mathrm{G} 2 / \mathrm{M}$ phase, an indicator of cellular mitosis or cell division, dropped from $30.4 \%$ to $16.2 \%$ as compared to TPL single treatment. The decrease in G2/M phase during the combination therapy was due to the increased cell cycle arrest in G0/G1 phase (from 29.8\% for TPL single treatment to 
43.6\% for TPL and ATF combined treatment). These results indicate that the major effect of TPL on cell cycle is $S$ phase arrest, and ATF can reinforce the cell proliferation inhibition effect of TPL by endowing with additional ability of G0/G1 cell cycle arrest.

\section{Combined effect of TPL and ATF on HUVEC and HCT116 cell migration}

In order to precisely characterize the effect of TPL and ATF on endothelial cell and tumour cell migration, serum stimulated haptotaxis motility, measured by the transwell motility chamber assay, was used to examine the effect of TPL and ATF on HUVEC and HCT116 cell migration. As shown in Figure 6A, the cells migrating to the lower membrane were stained and quantified. We found that, at a low dosage, ATF or TPL alone showed slight inhibition of cell migration. However, combined treatment with TPL and ATF showed more significant

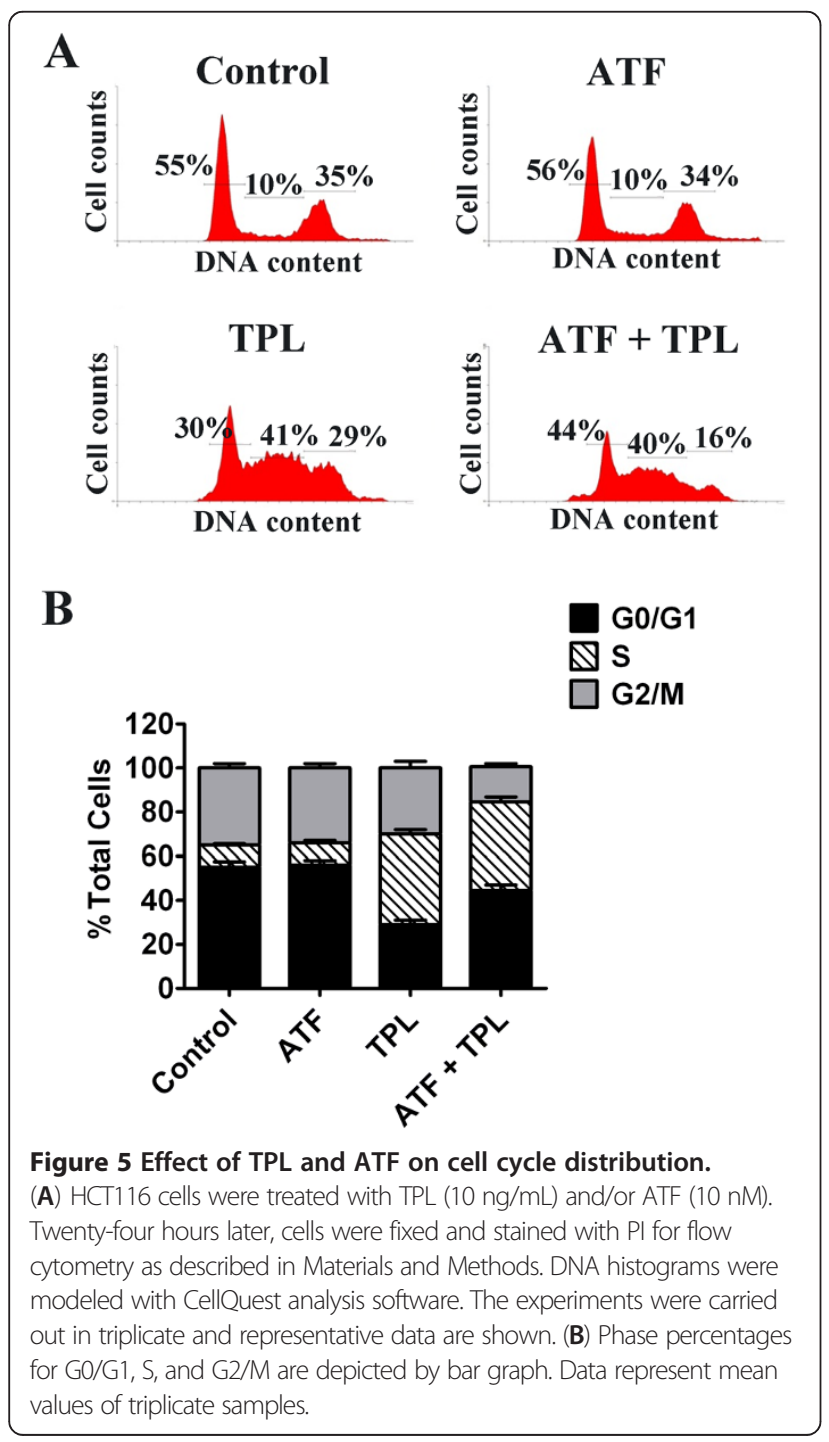

inhibition of cell migration than single therapy alone, which reduced the migration of HUVECs by $71.6 \%$ or $58.2 \%$ compared with control PBS group or ATF group, respectively. Similar results were also obtained in HCT116 cells. As we know, uPAR-dependent cell signalling events impact cell migration and survival. To explore the mechanisms underlying TPL and ATF combined effect on cell migration, Western blotting analysis was further accessed to determine the protein expression level of FAK and UPAR, which have been demonstrated to play important roles in cell migration. The results indicated that combined treatment with TPL and ATF significantly decreased phosphorylation level of FAK, while total FAK protein remained unchanged. In contrast, TPL or ATF alone had no effect on the phosphorylation of FAK. Similar results were observed in UPAR protein expression. Decreased expression level of UPAR was found in co-treated cells, compared with ATF or TPL treatment alone (Figure $6 \mathrm{~B}$ ).

uPA/uPAR system was reported to induce MMPs activity in cancer cells and then promote cancer cell migration and metastatic potential [35]. Previous reports suggested that down-regulation of uPAR decreased the expression of MMP-2 and MMP-9 [36]. Consistently, our qPCR results showed that combined treatment with TPL and ATF decreased the mRNA level of MMP-9 in HCT116 cells. However, no obvious inhibitive effect on mRNA expression of MMP-2 was found in cells cotreated with TPL and ATF (Figure 6C).

\section{Combination of TPL and ATF retarded the development of colon cancer xenografts in nude mice}

The antitumor effect of TPL in combination with ATF was analyzed in a xenograft tumour model by transplanting HCT116 cancer cells into athymic nude mice. On the 7th day post-implantation, mice were randomly divided into 4 groups before the tumour was palpated, with at least 8 tumour-bearing mice in each group. Tumour volume was significantly reduced after intraperitoneally injection of TPL and ATF for 21 days as compared to TPL or ATF Monotherapy (Figure 7A). Both TPL and ATF monotherapy also inhibited the growth of xenograft tumours to some extent, but the effects were not as significant as those seen in the combined treatment group. At the end of the study, we removed the tumours and measured their weight for each group. Combined treatment with TPL and ATF clearly reduced tumour weight compared with the control group, ATF or TPL single treatment (Figure 7B). Tumour doubling time was prolonged from 4.67 days in mice receiving PBS, 6.12 days in mice receiving ATF, 6.43 days in mice receiving TPL to 9.05 days in mice receiving TPL + ATF $(p<0.05 ; \mathrm{CI}=1.36$; Figure $7 \mathrm{C})$, indicating a supra-additive or synergistic effect of TPL and 


\section{A}

HUVEC

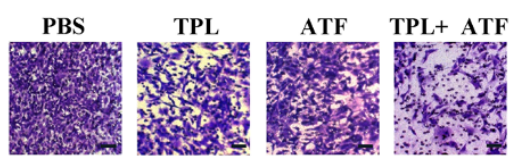

HUVEC
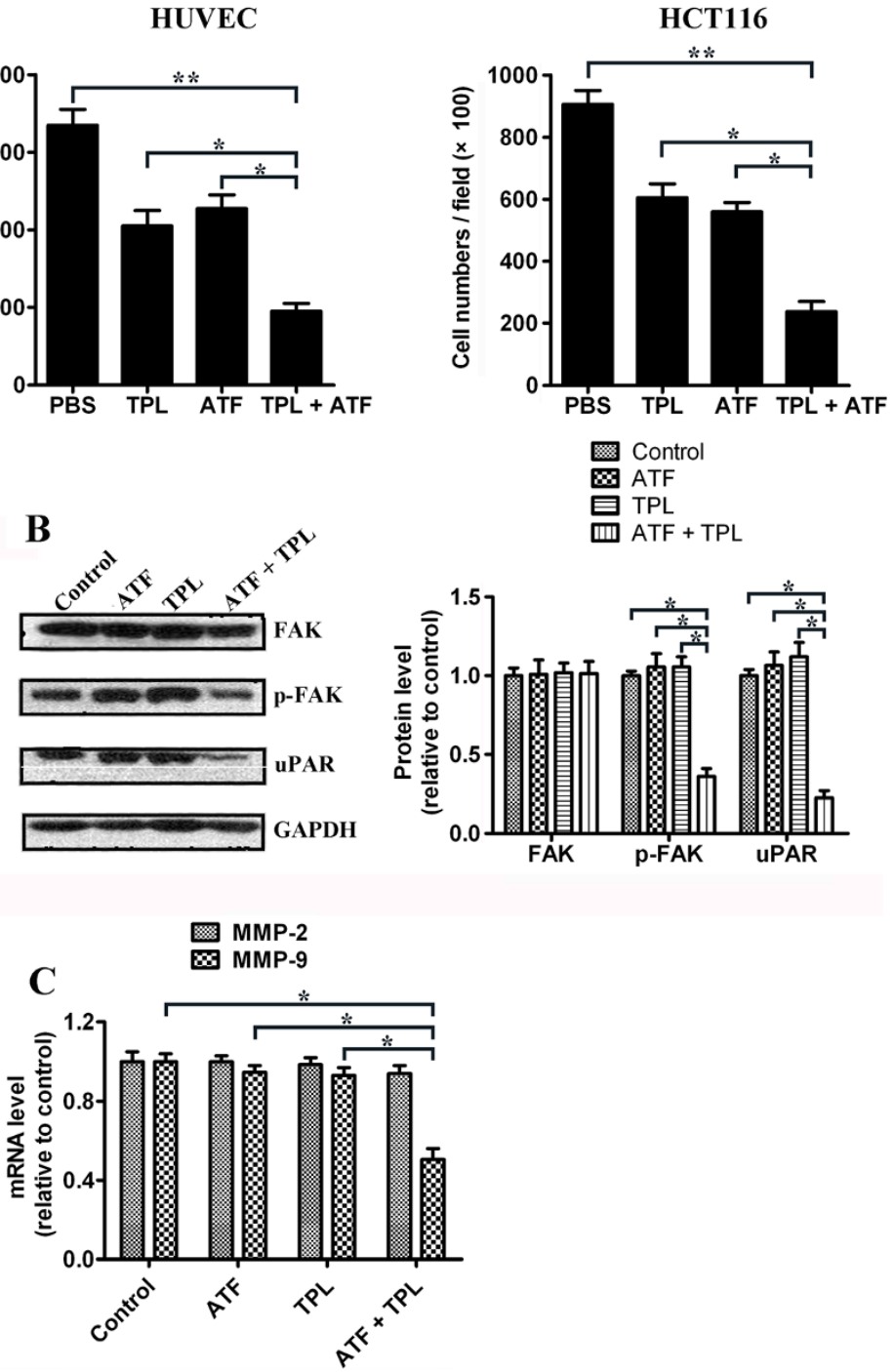

Figure 6 Effect of TPL and ATF on cell migration. (A) Transwell assay. HUVECs and HCT116 cells were treated with TPL (10 ng/mL) and/or ATF (10 $\mathrm{nM})$. After $16 \mathrm{~h}$ pretreatment and $9 \mathrm{~h}$ incubation in the upper chamber, the cells migrating to the lower membrane were stained and counted in five fields with a magnification of $\times 100 . N=3, b a r=50 \mu \mathrm{m}$. The experiments were carried out in triplicate and representative data are shown. (B) Effects of TPL and ATF on UPAR, FAK and p-FAK protein expression. HCT116 cells were treated with TPL (10 ng/mL) and/or ATF (10 nM). Twenty-four hours later, cells were harvested for Western blotting analysis using indicated antibodies. The level of GAPDH served as the loading control. Band intensities were calculated using software Image J. Relative intensities are also shown. Data represent mean values of triplicate samples. (C) HCT116 cells were treated with TPL (10 ng/mL) and/or ATF (10 nM). Twenty-four hours later, cells were harvested for RNA extraction and quantitative real time PCR using primers specific for human MMP-2, MMP-9, and GAPDH (internal control). Data represent mean values of triplicate samples. ${ }^{*} p<0.05,{ }^{*} p<0.01$.

ATF. In addition, no significant change in body weight was observed in mice treated with TPL alone, ATF alone, or TPL and ATF combined treatment (Figure 7D), indicating that there is no obvious toxicity for all of the treatment regimens. Furthermore, light microscopy revealed that tumour tissues in mice receiving TPL and ATF displayed more severe necrosis than control or TPL or ATF single therapy (Figure 7E). The percentage of necrotic area in tumours increased from $12.7 \%$ in mice receiving $\mathrm{PBS}, 26.2 \%$ in mice receiving 


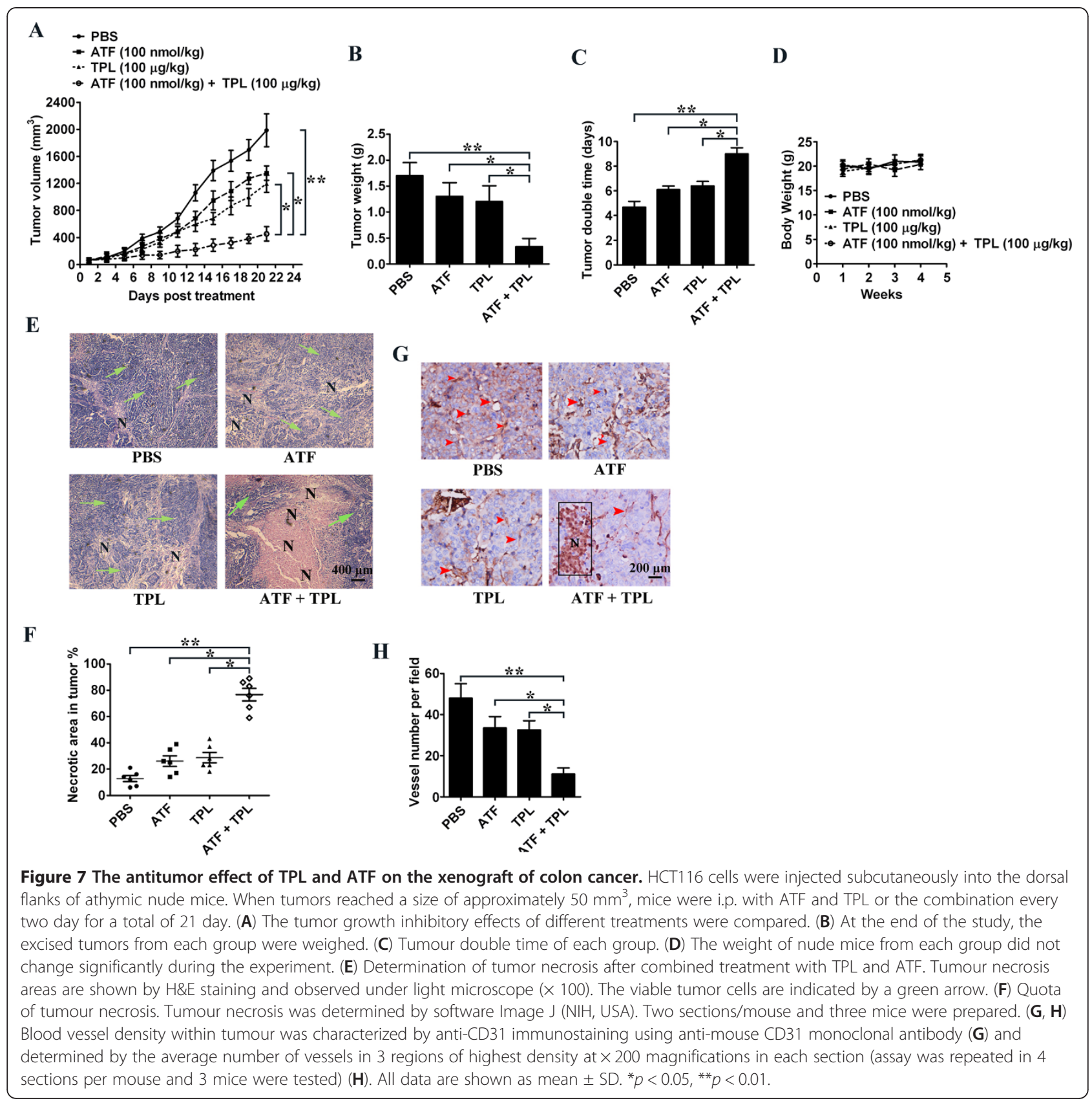

ATF, $28.7 \%$ in mice receiving TPL to $76.4 \%$ in mice receiving TPL + ATF (Figure 7F). TPL and ATF single therapy or untreated control displayed tissue necrosis interspersed with viable tumour cells, whereas TPL and ATF combined treatment induced large areas of continuous necrosis within tumours (Figure 7E). Immunohistochemical studies further revealed that TPL and ATF combined treatment markedly reduced the expression of CD31, a marker of neoangiogenesis (Figure 7G and $7 \mathrm{H}$ ), suggesting that combination of TPL and ATF could inhibit tumour progression primarily through suppressing tumour-related angiogenesis.

\section{Discussion}

Colon cancer remains a major public health threat and accounts for approximately $13 \%$ of all cancers [37]. More effective treatments and earlier detection have led to improved survival over recent decades. However, around $50 \%$ of newly diagnosed colon cancer patients will eventually progress due to micro metastases, and die of their disease, in spite of the advances in surgical techniques and radiotherapy. Therefore chemotherapy becomes one of the most important means of extending the survival of colon cancer patients. The development of cancer involves a complex interplay among cellular processes, 
and treatment with a single agent is rarely effective. Combination therapy is now considered to be a standard approach to chemotherapy [38]. There are many advantages to combination therapy, including the targeting of multiple critical molecular processes, delivery of lower dose agents with lower toxicity, and increased patient tolerance. The effectiveness of combination chemotherapy has stimulated an interest in exploring drugs with different modes of activity at lower dosages [39].

The coordinated interaction of different proteolytic systems is important for tumour cell invasion and metastasis [40]. The invasive capacity of tumour cells can be suppressed by synthetic inhibitors against various proteases or by plasminogen activator system antagonists. The uPA system has pivotal roles in tumour growth, angiogenesis, and metastasis [41]. The binding of UPA to UPAR has been shown to mediate various other signalling cascades [42], although the role of these cascades in tumour progression is poorly understood. Since the UPA-uPAR system contributes to the invasion and motility of several cell types associated with tumour progression, the inhibition of the UPA-uPAR interaction may have significant antitumor effects. ATF, the amino terminal fragment of urokinase, has been demonstrated to act as an angiostatic molecule that targets the uPAuPAR system and inhibits cell invasion and migration. By blocking the attachment of uPA to uPAR, ATF could effectively shut down the plasmin activation on the surface of both tumour and activated endothelial cells, which is essential for angiogenesis-related ECM degradation, new blood vessel formation, and accordingly the invasive phenotype of primary tumours $[14,15]$. In a recent study, the invasiveness of a highly metastatic human lung giant-cell carcinoma cell line transfected with ATF cDNA was significantly inhibited in vitro, as was the lung metastasis of implanted cells in a spontaneous metastasis model [43]. Li et al. also showed that adenovirus-mediated delivery of ATF suppressed growth of xenografted MDA-MB-231 human breast cancer cells grown in athymic mice [44]. These data suggests that ATF is a good candidate for cancer therapy. Nevertheless, the clinical experience and treatment of other solid tumours tell us that only a few solid tumours respond to single agent-based therapy. Chronic exposure to chemotherapeutic agents can induce the selection of clones that are resistant to that particular agent; therefore, overtime tumour resistance can occur. Additionally, solid organ tumours sometimes have intrinsic resistance to the drug before any treatment has started. It cannot be overemphasized that the probability that drug resistance develops over the course of the disease decreases if different agents are combined. Combined therapy also allows decreasing drug doses, decreasing the likelihood of toxicity.
TPL, a natural, active compound isolated from Tripterygium wilfordii Hook F, is known to induce apoptosis in several cancer cell types by activating both the extrinsic and intrinsic pathways of apoptosis in tumours [21]. As a promising immune-suppressor, TPL has been widely used in Chinese medicine. TPL has multiple pharmacological activities, including anti-inflammatory, immunosuppressive, male anti-fertility and anticancer effects $[45,46]$. Research into its mechanisms of action has revealed that it potently inhibits monocyte activation, activates caspases and other pro-apoptotic signalling cascades, inhibits angiogenesis and reverses drug resistance $[47,48]$. Recent studies demonstrate that TPL also possesses anti-cancer activity and inhibits cancer cell proliferation in vitro and in vivo [21]. Although TPL alone was very effective to kill tumour cell lines, it is not curative and the safe dose range for in vivo application is relatively narrow. A major concern about using TPL for clinical antitumor applications is its toxicity. Shamon et al. [49] reported that TPL exerted a modest antitumor activity when administered at a dose of $25 \mu \mathrm{g}$ /mouse 3 times per week intravenously to nude mice carrying human breast tumors, but higher doses $(50 \mu \mathrm{g} /$ mouse $)$ were lethal, suggesting a narrow therapeutic window of TPL treatment. Severe side effects happened in a recent phase I clinical study using F60008 [50], which is a semi-synthetic derivate of TPL, in patients with solid tumours. In preliminary study, we found that i.p. administration of $100 \mu \mathrm{g} / \mathrm{kg}$ doses of TPL exerted slight antitumor effects, and that the mice treated with $100 \mu \mathrm{g} / \mathrm{kg}$ TPL did not show any obvious side effects. However, weight loss, skin inflammation and vessel inflammation were observed in the mice treated with $400 \mu \mathrm{g} / \mathrm{kg} \mathrm{TPL}$, and higher doses of TPL displayed stronger effects but the side effects were more severe (data not shown). Therefore it would be much more beneficial if it can be used at a relatively lower dose to sensitize the cytotoxicity of other anti-cancer drugs. TPL has been shown great value when used in combination with other antitumor treatments, inducing higher levels of cell death by increasing tumour cell sensitivity to chemotherapy or radiation. Previous studies indicate that TPL can efficiently enhance the cytotoxicity of some cytokines and anti-cancer drugs $[24,51,52]$.

Since both ATF and TPL exhibit antitumor activity, we formulated the hypothesis that combined therapy with these two drugs increases the effectiveness as compared with single therapy. In this study, we tested the in vitro and in vivo enhancing effect of TPL on the cytotoxicity of ATF in a panel of solid tumour cell lines. Using MTT assay we found that TPL inhibited the growth and proliferation of ATF-treated tumour cells synergistically. Compared to TPL or ATF alone, low dosage of these two drugs in combination induced 
substantial apoptosis of tumour cells. Cell apoptosis is known to be programmed and finally executed by caspase-3, through several signalling pathways involved in apoptosis regulation. To further exploit the antitumor mechanism of TPL and ATF, we detected the activation of caspase-9, caspase-3 and NF-kB/p65. Our results indicated that induced apoptosis of HCT116 cells by the combination of TPL and ATF was mediated through caspase-9/caspase-3 activation and NF-kB/p65 inhibition. In turn, caspases activation led to PARP cleavage, DNA damage and fragmentation, nuclear condensation, and eventually, the induction of apoptosis. NF-kB/p65 that comprises a heterotrimer of p50 and p 65 binds to its inhibitory protein $I_{\kappa} \mathrm{B} \alpha$, thereby leading to the release of the p50-p65 heterodimer, which then translocates to the nucleus and associates with the promoter regions of multiple target genes. In this study, we found that TPL and ATF combined treatment can down-regulate $\mathrm{NF}-\mathrm{kB} / \mathrm{p} 65$ protein expression and this finding is consistent with that of other reports $[53,54]$. NF- $\mathrm{B}$ is generally considered to be a survival factor that activates expression of various anti-apoptotic genes, e.g. Bcl-2, Bcl-xL, Mcl-1 and c-FLIP that block apoptosis [55]. Inhibition of NF- $\mathrm{kB}$ will lead to down-regulation of the NF-kB-regulated anti-apoptotic proteins, thereby promoting apoptotic cell death. Indeed, combined treatment with TPL and ATF significantly decreased the expression of c-FLIP, a well-known anti-apoptotic protein, and finally led to cell apoptosis. It has been reported that the ser/thr kinase AKT can promote NF$\kappa \mathrm{B}$ activity [31,32]. In the current study, we found that TPL and ATF combined treatment did not affect the total expression of AKT, but significantly decreased the phosphorylation level of AKT (Figure 4B). The inactivation of AKT may lead to transcriptional inhibition of $\mathrm{NF}-\mathrm{kB}$, and the previously well-characterized downregulation of c-FLIP expression by inactivated NF- $\mathrm{kB}$. In addition, co-treatment with TPL and ATF also led to JNK activation. The activation of JNK promotes apoptosis in a manner that is dependent on the cell type and the context of the stimulus. In the past, the contributions of the NF-kB and JNK pathways to cell death have been discussed independently. However, recent studies have indicated that one of the anti-apoptotic functions of NF-KB is to down-regulate JNK activation [56]. Therefore, we speculated that TPL and ATF in combination could activate JNK in tumor cells through inactivating $\mathrm{NF}-\mathrm{kB}$, thus contributing to apoptosis. In addition, the activation of JNK is also involved in the down-regulation of C-FLIP-L [57]. Thus, the inhibition of NF-kB, up-regulation of JNK activity and subsequently reduction of c-FLIP expression might contribute to the increased sensitivity to TPL and ATF-mediated apoptosis (Figure 8).
Cell cycle regulation is closely linked to cell proliferation, and one of the notable features of a tumour is abnormal cell cycle management. TPL has previously been shown to induce cell accumulation in the $\mathrm{S}$ phase [52,58]. Cell apoptosis seems like to be closely associated with the cell cycle arrest in $\mathrm{S}$ phase via accelerating cells into $S$ phase and hampering cells out from $S$ phase. In human colon cancer cells, we confirmed that TPL accumulated cells in $\mathrm{S}$ phase and thus caused cell apoptosis. When in combination with ATF, cells were maintained the $S$ phase arrest and the population of cells in $G 2 / M$ phase was decreased as compared to TPL single therapy. Nevertheless, some researches demonstrated that TPL treatment triggered a G0/G1 cell cycle arrest and apoptosis in gastric cancer and multiple myeloma cells $[19,59]$. In our study, treatment with TPL alone caused S phase arrest, not G0/G1 arrest in HCT116 cells. However, ATF could help TPL to restore its ability of G0/G1 arrest, meanwhile retain its $\mathrm{S}$ phase arrest. Taken together, these results indicate that the cell cycle phase arrest TPL will induce is cancer cell type-specific and ATF can enhance the cell cycle arrest ability of TPL, thus eventually increasing cell apoptosis. In addition, NF- $\mathrm{B}$ also plays a crucial role on cell cycle by regulating key proto-oncogenes, including Cyclin D1, c-Myc and Skp2 [60]. Thus, the inhibition of NF- $\mathrm{BB}$ may partially contribute to cell cycle arrest by combined treatment with TPL and ATF (Figure 8).

Cell motility is one of the prerequisites for the invasion and metastasis of malignant tumours. Most cancer patients do not die from local complications of their primary tumour growth, but rather from the development and spread of the tumour. Therefore, metastasis is one of hallmarks of malignant tumour and a major cause of death among cancer patients. Several reports have indicated that TPL can reduce the growth and metastasis of tumours in vivo and in vitro, via inhibition of heat shock protein 70 (HSP70), CXC chemokine receptor 4 (CXCR4), or uPAR [61-63]. In this study, we found that, in the presence of ATF at a low concentration, the motility of tumour cells was decreased, which clearly demonstrated that ATF alone could partially inhibit this step. When combined with TPL, the inhibition of tumour cells migration was significantly enhanced. Mohanam et al. reported that a glioma cell line over-expressing ATF exhibited impaired adhesion, motility and colonization, the mechanism underlying those phenotypes was the rearrangement of cytoskeleton [15]. Cell motility is made up with successive attachment and detachment. Upon the binding of UPA, UPAR is subjected to directly interacting with vitronectin, and thereby improved the cell adhesion and attachment $[64,65]$. In the presence of PAI-1, the complex containing uPA-PAI-1UPAR will be engulfed by cell, accompanied with the 


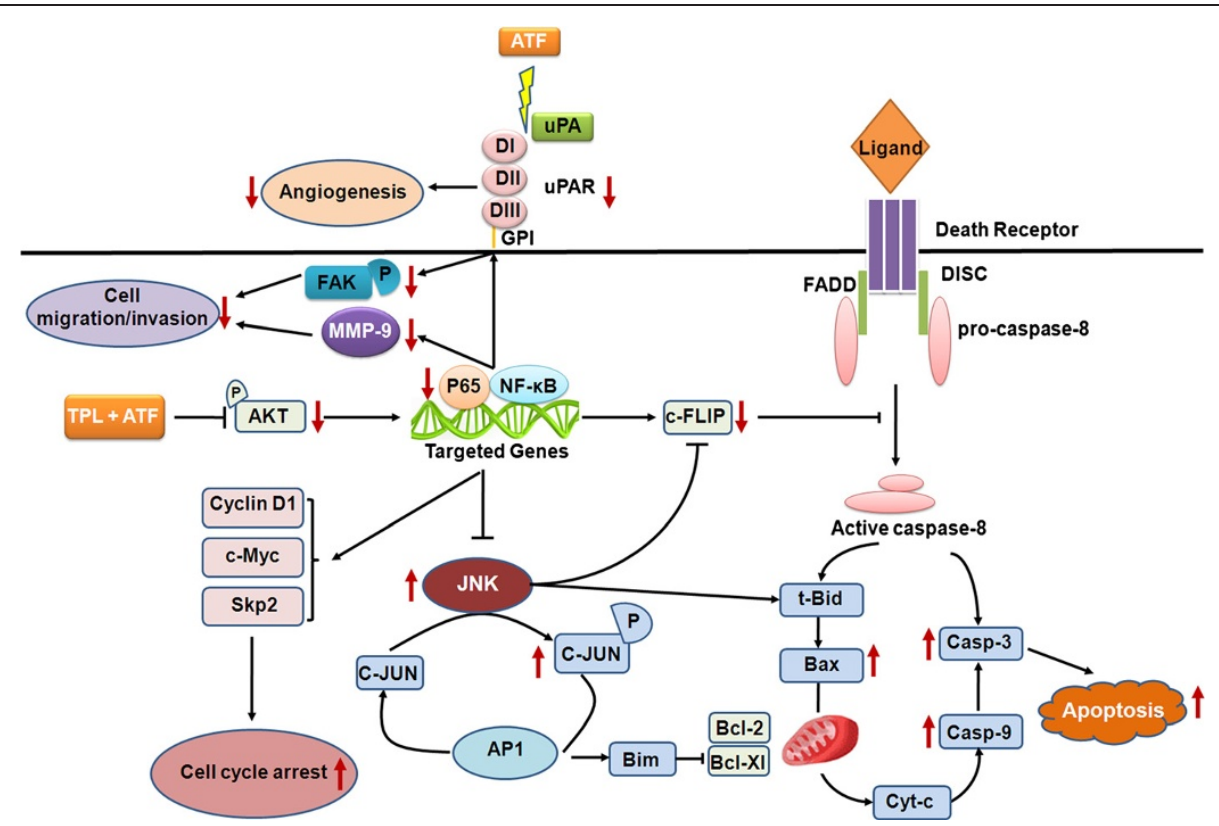

Figure 8 A working model for the synergistic effect of TPL and ATF on tumour cells. TPL and ATF cooperatively induce apoptosis through caspase-dependent pathway and cell cycle arrest. In HCT116 cells, combined treatment with TPL and ATF at a low dosage inhibits AKT phosphorylation and subsequently inactivates NF-KB. The inhibition of NF-KB leads to down-regulation of c-FLIP, activation of caspases-9/caspase-3 and JNK-c-JUN pathway, and cell cycle arrest, which finally promotes cell apoptosis. In addition, the suppression of NF-KB leads to decreased expression of uPAR, MMP-9 and phospho-FAK, thereby inhibiting tumor cell migration and invasion. Furthermore, ATF can segregate UPA from its receptor uPAR, thus blocking ECM remodeling and anti-angiogenesis processes.

degradation of uPA-PAI within lysosome and the recycling of intact uPAR to cell surface. This process may induce the occurrence of cell detachment [66]. Presumably, ATF slows the movement by impairing the recycling of uPAR on the cell surface. Unlike uPA, ATF is incapable of binding PAI-1 $[66,67]$, which blocks the uPAR recycling and attenuates the attachmentdetachment cycle. Therefore, cells overexpressing uPAR may adapt to be quiescent upon the ATF binding. To further clarify the mechanisms underlying combined effect of TPL and ATF on cell migration, we examined the uPAR-dependent signalling pathway. We found that, combined treatment with TPL and ATF led to inhibition of UPAR and FAK phosphorylation significantly. Specifically, treatment of HCT116 cells with ATF or TPL alone did not affect the expression level of uPAR protein and downstream FAK phosphorylation, thus indicating that the inhibition of cell migration was not an additive but indeed a cooperative effect of TPL and ATF. It is reported that TPL inhibits UPAR expression via blocking NF- $\kappa B$ signalling [63]. Thus, we speculated that low dosage of TPL and ATF in combination led to inhibition of NF- $\kappa B$, which finally down-regulated uPAR expression. Furthermore, inhibition of NF- $\mathrm{kB}$ pathway may also down-regulate uPA [68]. In mammary tumour cells, uPA binding to uPAR activates FAK through a still unknown partner molecule [69]. Thus, the down-regulation of
UPA and UPAR may lead to subsequent decreased phosphorylation level of FAK. Taken together, these results provide evidence that TPL and ATF combinationtriggered inhibition of cell migration is probably mediated through NF-кB-uPA/uPAR-FAK-dependent cell signalling pathways (Figure 8). Additionally, we found that combined treatment of ATF and TPL decreased the mRNA level of MMP9 but not MMP2 in HCT116 cells, which are mainly involved in the metastasis process. On the contrast, ATF or TPL single therapy had no obvious effect on MMP-9 expression, indicating that the expression of MMP-9 is synergistically regulated by TPL and ATF. Although MMP-9 shares fairly broad substrate specificity and structure features with MMP-2, both enzymes differ considerably in terms of transcriptional regulation. The $5^{\prime}$ flanking sequence of MMP-9 gene harbors NF- $\mathrm{kB}$ binding sites, while the expression of MMP-2 is mainly regulated by SP-1 [70]. The combined effect of TPL and ATF on MMP-9 expression is probably through NF-KB inhibition. These could be presumed to be one of the reasons for different effect of TPL and ATF on the gene expression of MMP-9, compared with MMP-2.

uPA-uPAR system plays a crucial role in the ECM degradation and remodelling in the process of angiogenesis, thereby may affect the formation of neovessel structure and the tumour development [3]. In the in vivo tumour 
model experiment, low dosage of ATF inhibited tumour growth by blocking the proteolytic cascade initiated by uPA-uPAR interaction. Moreover, its antitumor effects could be further enhanced by TPL at a low dosage, suggesting a promising strategy to treat the devastating disease. During the development of colon cancer within nude mice, the tumour cells recruit murine endothelial cells to establish a network of new blood vessel. Human and mouse ATF are species specific. When entering into the circulation system, ATF was speculated to target only tumour cells instead of both the tumour and endothelial cells. Therefore, the anti-angiogenesis and antitumor activity may be partially compromised. We assumed that the antitumor function of ATF was achieved by its suppressive capacity against angiogenesis, which owes to its competitive interaction with UPAR towards uPA. In this case, TPL does not show species specific and can target both tumour and endothelial cells. Thus, when combined with TPL, ATF induced significantly increased antitumor and anti-angiogenesis efficiency. It is worth paying attention that only one colon cancer cell line was investigated in in vivo experiment in this study. More cancer cell lines are required to be studied in vivo to evaluate the therapeutic application of TPL and ATF combination on cancer in future.

\section{Conclusions}

In summary, we provided evidence that TPL potently inhibited the growth of human solid tumour cell lines in vitro. We have also demonstrated that TPL, at a low concentration, synergistically induced cell apoptosis through multiple targets including caspases and NF- $\mathrm{KB}$ pathways in various tumour cell lines when combined with ATF (Figure 8). Furthermore, combined treatment with the two drugs effectively reduced growth of xenografted HCT116 cells grown in athymic mice without exhibiting any toxicity in the animals. Based on the synergistic antitumor activity profiles of combined TPL and ATF treatments in vitro and in vivo and the absence of cytotoxicity in normal tissues, we believe that TPL has strong therapeutic value for use in combination with ATF against colon cancer.

\section{Methods}

\section{Cells, cell culture, and reagents}

Human A549 lung adenocarcinoma cell line, human HCT116 colon cancer cell line, human breast cancer metastatic cell MDA-MB-231, human cervical carcinoma HeLa cell line, human embryonic renal HEK293 cells and human umbilical vein endothelial cells (HUVECs) were purchased from the American Type Culture Collection (ATCC, Philadelphia, PA, USA). MDA-MB-231, HeLa and HEK293 cells were grown in Dulbecco's modified Eagle's medium (DMEM) (HyClone, Logan, UT, USA) supplemented with
$10 \%(\mathrm{v} / \mathrm{v})$ fetal bovine serum (HyClone, Logan, UT, USA) and $1 \%$ penicillin-streptomycin (Invitrogen, Carlsbad, CA, USA). A549 and HCT116 cells were grown in RPMI 1640 (HyClone, Logan, UT, USA) supplemented with 10\% (v/v) fetal bovine serum (HyClone, Logan, UT, USA) and 1\% penicillin-streptomycin (Invitrogen, Carlsbad, CA, USA). HUVECs were grown in Medium 200 (Cascade Biologics, Portland, OR, USA) supplemented with Low Serum Growth Supplement (LSGS). All cells were cultured in a humidified $\mathrm{CO}_{2}$ incubator at $37^{\circ} \mathrm{C}$. TPL $(99 \%$ purity, Sigma-Aldrich, St. Louis, MO, USA) was solubilised in $0.01 \%$ dimethyl sulfoxide (DMSO) in phosphate buffered saline (PBS), filtered through a $0.2 \mu \mathrm{m}$ Millipore filter and kept at $-70^{\circ} \mathrm{C}$. Annexin V and propidium iodide (PI) were purchased from Molecular Probes (Eugene, OR, USA).

\section{Expression and purification of ATF in Pichia pastoris}

The plasmid pGAPZ $\alpha$ A-ATF for the expression of ATF was constructed previously in our laboratory by Dr. Jianping Li. Plasmid DNA was then linearized at the Bln I site and electroporated into the yeast host strain X-33 (Invitrogen, Carlsbad, CA, USA). Recombinants were selected on YPDS plates (10 g/L yeast extract, $20 \mathrm{~g} / \mathrm{L}$ peptone, $20 \mathrm{~g} / \mathrm{L}$ dextrose, $20 \mathrm{~g} / \mathrm{L}$ agar, and $1 \mathrm{M}$ sorbitol) and characterized for expression of ATF. A single positive clone of Zeocin-resistant was selected with a view to produce the specific protein. A preculture growth step was performed for $24 \mathrm{~h}$ in a $250 \mathrm{~mL}$ Erlenmeyer flask containing $50 \mathrm{~mL}$ YPD medium. This cell culture was further used to inoculate larger yeast cell cultures at an optical density $\left(\mathrm{OD}_{600 \mathrm{~nm}}\right)$ of 1 , to start the cell growth directly in the exponential growth phase, as well as to establish reproducible cell culture conditions. The yeast was further grown at $30^{\circ} \mathrm{C}$ with orbital agitation at a rate of $250 \mathrm{rpm}$. The optimum YPD medium to flask volume ratio for ATF production was found to be $1 / 5$ and the cultures were usually performed in a 1-L Erlenmeyer flask containing $200 \mathrm{~mL}$ YPD medium without any Zeocin. The cultures were stopped after $72 \mathrm{~h}$ and the cells were pelleted by centrifugation at $3000 \times g$ for $20 \mathrm{~min}$. Culture supernatants from shaker flasks were precipitated with ammonium sulphate (65\% saturation). The precipitate was then dissolved in buffer A (20 mM sodium acetate, $1 \mathrm{mM}$ EDTA, $0.5 \mathrm{mM}$ PMSF, $\mathrm{pH} 4.8$ ), and finally dialyzed against the same buffer at $4^{\circ} \mathrm{C}$. Further purification was carried out by CM Sepharose Fast Flow column (GE Healthcare). After loading the sample, the column was washed with buffer B $(20 \mathrm{mM}$ sodium acetate, $1 \mathrm{mM}$ EDTA, $\mathrm{pH} 4.8$ ) and stepwise eluted by $0.1 \mathrm{M}, 0.2 \mathrm{M}, 0.5 \mathrm{M} \mathrm{NaCl}$ in buffer B. The eluted fractions were pooled and the concentration of ATF was determined by the Bio-Rad protein assay method (Bio-Rad, Hercules, CA). The purity was determined on a SDSPAGE gel stained with Coomassie Blue. The identity of 
ATF was confirmed by Western blotting using polyclonal mouse anti-ATF antibody (Santa Cruz Biotechnology, Santa Cruz, CA).

\section{Cell proliferation assay}

The effects of ATF, TPL or the combination on cell proliferation were assessed by the MTT assay. Cells in the exponential growth phase were seeded into a 96-well plate at a density of 5000 cells per well. After $24 \mathrm{~h}$, ATF (10 nM), TPL (10 ng/mL) or the combination were added to the medium. The cells were incubated at $37^{\circ} \mathrm{C}$ for $24 \mathrm{~h}$, then the cell viability was determined by the colorimetric MTT [3-(4, 5dimethylthiazol-2-yl)-2, 5-diphenyl-2H-tetrazolium bromide] assay at wave length $570 \mathrm{~nm}$ by TECAN Safire Fluorescence Absorbance and Luminescence Reader (Vienna, VA, USA). The cell viability was calculated according to the formula: Cell viability $(\%)=$ average $A_{570 ~ n m}$ of treated group/ average $A_{570} \mathrm{~nm}$ of control group $\times 100 \%$. Each experiment was performed in quadruplicate and repeated at least three times. To determine whether TPL in combination with ATF worked synergistically, the combination index (CI) in MTT assay was calculated as follows: $\mathrm{CI}=\mathrm{AB} /(\mathrm{A} \times \mathrm{B})$. According to cell viability of each treatment, $A B$ is the ratio of the combination treatment to the control treatment; A or $\mathrm{B}$ is the ratio of the single agent treatment to the control treatment. Thus a CI value less than, equal to or greater than 1 indicates that the drugs are synergistic, additive or antagonistic, respectively. A CI less than 0.7 indicates that the drugs are significantly synergistic.

\section{Annexin V-fluorescein isothiocyanate/propidium iodide assay}

To quantify the percentage of cells undergoing apoptosis, we used the Annexin V-FITC kit as described by the manufacturer. Briefly, HCT116 and A549 cells were incubated for 24 hours with TPL $(10 \mathrm{ng} / \mathrm{mL})$ and ATF $(10 \mathrm{nM})$ alone or in combination. Next, the treated cells were collected and trypsinized for 3-5 min. The digested cells were washed twice with cold PBS and resuspended in binding buffer at a concentration of $1 \times 10^{6}$ cells $/ \mathrm{mL}$. After incubation, $100 \mu \mathrm{L}$ of the solution was transferred to a $5 \mathrm{~mL}$ culture tube, and $5 \mu \mathrm{L}$ of Annexin V-FITC and $10 \mu \mathrm{L}$ of PI were added. The tube was gently centrifuged and incubated for $15 \mathrm{~min}$ at room temperature in the dark. At the end of incubation, $400 \mu \mathrm{L}$ of binding buffer was added, and the cells were analyzed immediately by flow cytometry (BD Biosciences, CA, USA). Flow cytometry analysis was performed with untreated HCT116 and A549 cells as control.

\section{Cell cycle analysis}

HCT116 cells $\left(2 \times 10^{6}\right)$ were treated with TPL $(10 \mathrm{ng} / \mathrm{mL})$ and ATF $(10 \mathrm{nM})$ alone or in combination for $24 \mathrm{~h}$. Cells were then harvested, washed in PBS, resuspended gently in $5 \mathrm{~mL}$ of $100 \%$ ethanol, and fixed at $25^{\circ} \mathrm{C}$ for $1 \mathrm{~h}$. After washing with PBS, cells were incubated with DNase-free RNase A $(200 \mu \mathrm{g} / \mathrm{mL})$ at $37^{\circ} \mathrm{C}$ for $1 \mathrm{~h}$ and washed with PBS. PI $(10 \mu \mathrm{g} / \mathrm{mL})$ was added and the cells were incubated at $37^{\circ} \mathrm{C}$ for $5 \mathrm{~min}$. The distribution of cells with differing DNA content was analyzed on a FACSCalibur flow cytometer with CellQuest software (BD Biosciences, CA, USA) at an excitation wavelength of $530 \mathrm{~nm}$. Fluorescence emission was measured using a $620 \mathrm{~nm}$ band pass filter.

\section{Caspase activity assay}

Caspase- 3 and caspase- 9 activities were measured using colorimetric activity assay kits (Chemicon International, CA, USA). The assay is based on the cleavage of the chromogenic substrates, DEVD-pNA and LEHD-pNA, by caspase- 3 and caspase-9, respectively. Cells were lysed in chilled lysis buffer on ice for $10 \mathrm{~min}$ and centrifuged for $5 \mathrm{~min}$ at $10,000 \times g$. Caspase substrate solution containing the specific peptide substrate was then added to the supernatant and incubated for $2 \mathrm{~h}$ at $37^{\circ} \mathrm{C}$ before measurement by ELISA reader at $405 \mathrm{~nm}$.

\section{RNA interference}

The siRNA against NF- $\mathrm{kB}$ p65 (sc-29410) was purchased from Santa Cruz Biotechnology, Santa Cruz, CA. For transfection with siRNAs, logarithmically growing cells were transfected with siRNA as instructed by the manufacturer.

\section{Western blot analysis}

HCT116 cells were incubated with TPL (10 ng/mL) and ATF (10 nM) alone or in combination for $24 \mathrm{~h}$, then lysed with RIPA buffer (Beyotime, China) with protease inhibitor cocktail tablets (Complete Mini, EDTA free; Roche, Basel, Switzerland). Supernatants were collected and protein concentration was determined by the Bio-Rad protein assay method (Bio-Rad, Hercules, CA). Western blotting was performed according to standard protocols. Proteins were separated by SDS-PAGE and transferred onto nitrocellulose membranes that were blocked with 5\% non-fat milk in TBS containing $0.1 \%$ Tween 20, and incubated with primary antibodies: p-FAK (Tyr 397), FAK, p-JNK, c-JUN, p-c-JUN, p-AKT (Ser 473), uPAR, cleaved caspase-3 (Cell Signalling Technology, Beverly, MA, USA), NF-кB p65 (Invitrogen, Carlsbad, CA), BAX, BAD, BAK, cIAP, poly (ADP-ribose) polymerase (PARP), $\alpha$-tubulin, c-FLIP-L, GAPDH, Lamin B (Santa Cruz Biotechnology, Santa Cruz, CA). Secondary antibodies were coupled to horseradish peroxidase, and were goat anti-rabbit or goat anti-mouse. Bound antibodies were then visualized with ECL plus Western blotting detection reagents (GE Healthcare). Signal intensity was quantified by densitometry using the software Image J $(\mathrm{NIH}$, Bethesda, MD). All experiments were done in triplicate and performed at least three times independently. 


\section{RNA extraction and quantitative real-time PCR}

Total RNA was extracted from treated cells using a TRIzol reagent (Invitrogen, Carlsbad, CA, USA) following the manufacturer's instructions and was used to prepare cDNA by PrimeScript RT reagent Kit (Takara, Otsu, Shiga, Japan). Quantitative real-time PCR was performed with SsoFast EvaGreen Supermix on a CFX96 Real-Time System (Bio-Rad Laboratories, Hercules, CA, USA). The sequences of PCR primers used in our study were synthesized commercially, and are shown as follows: MMP-2 upstream: 5' -CCGTCGCCCA TCATCAA- 3'; MMP-2 downstream: 5' GGTATTGCA CTGCCAACTCTTTG- 3'; MMP- upstream: 5' GGA CGATGCCTGCAAGT- 3'; MMP-9 downstream: 5' -A CAAATACAGCTGGTTCCCAATC- 3 '. The glyceraldehyde 3-phosphatase dehydrogenase (GAPDH) gene was used as the reference gene. All data were means of fold change of triplicate analysis and normalized with those of GAPDH.

\section{Cell migration assay}

The effects of ATF, TPL or the combination on endothelial cell and tumor cell migration were assessed by the transwell assay. The cell migration assay was performed using transwell inserts $(8.0 \mathrm{~mm}$ pore size, Millipore, Billerica, MA, USA) as described previously [71]. Before the experiment, HUVECs and HCT116 cells had been cultured in serum-free medium with ATF $(10 \mathrm{nM})$, TPL $(10 \mathrm{ng} / \mathrm{mL}$ ) or the combination (PBS used as buffer control) for $16 \mathrm{~h}$. Then the cells were harvested and resuspended in the same medium. $1 \times 10^{5}$ cells in a volume of $0.1 \mathrm{~mL}$ were added to the upper chamber, and the lower chamber was filled with $0.6 \mathrm{~mL}$ of $20 \% \mathrm{FBS}$ supplemented medium. After incubation at $37^{\circ} \mathrm{C}$ for $9 \mathrm{~h}$, cells on the upper surface of the membrane were removed. The migrant cells attached to the lower surface were fixed in 10\% formalin at room temperature for $30 \mathrm{~min}$, and stained for $20 \mathrm{~min}$ with a solution containing $1 \%$ crystal violet and $2 \%$ ethanol in $100 \mathrm{mM}$ borate buffer ( $\mathrm{pH}$ 9.0). The number of cells migrating to the lower surface of the membrane was counted in five fields under a microscope with a magnification of $\times 100$. All groups of experiments were conducted in triplicate, and the cell number was counted by Image-Pro Plus 6.0 software.

\section{In vivo animal tumour model experiment}

Athymic nude mice (6-8 weeks of age) were obtained from Shanghai Laboratory Animal Centre (Shanghai, China) and housed under germfree conditions. Animal care and use were performed strictly in accordance with the ethical guidelines by Nanjing University Animal Care and Use Committee and the study protocol was approved by the local institution review board. HCT116 cells $\left(2 \times 10^{6}\right.$ cells in $\left.50 \mu \mathrm{L}\right)$ were injected subcutaneously into the dorsal flanks of mice. Tumour volume was monitored by measuring the two maximum perpendicular tumour diameters with callipers every alternate day. All tumour-bearing mice were divided randomly into 4 groups, and treatment was initiated on the 7th day when the volume of tumour reached a size of approximately $50 \mathrm{~mm}^{3}$. The mice were injected intraperitoneally (i.p.) with ATF $(100 \mathrm{nmol} / \mathrm{kg})$, TPL $(100 \mu \mathrm{g} / \mathrm{kg})$ or the combination every two day for a total of 21 day. Control mice received i.p. injection of PBS. Antitumor activity of treatments was evaluated by tumour growth inhibition. Tumours were measured individually with a calliper every other day, and the formula, tumour volume $=$ length $\times$ width $^{2} \times 0.52$ was used to mimic the tumour volume. At the end of study, the tumours were collected and weighed.

In a parallel animal assay (totally 4 groups, and 3 mice per group), the tumour establishment and drug treatment are the same as described earlier. On the 21th day, mice were euthanized. Tumours were collected, fixed with $4 \%$ formaldehyde, embedded in paraffin and sectioned for haematoxylin and eosin (H\&E) staining or immunostaining according to standard histological procedures. Blood vessel within tumours was immunostained with anti-mouse CD31 monoclonal antibody (BD Pharmingen, Franklin Lakes, NJ, USA) and determined by the average number of vessels in 3 regions of highest density at $200 \times$ magnifications in each section.

\section{Calculation of tumour doubling time and combination index}

The tumour doubling time (TDT) and combination index (CI) were calculated using GraphPad Prism v 5.0. TDT values were generated from exponential growth curves, which had been fitted to \% change in tumour volume data $\left(r^{2}>0.70\right)$. Our CI calculations were adapted [72] to apply to TDT values. First, the TDT value for untreated mice was subtracted from the TDT value for each treatment group to obtain 'blanked' TDT values $\left(\mathrm{TDT}_{\mathrm{B}}\right)$. Then, the CI was calculated as the ratio of $\mathrm{TDT}_{\mathrm{B}}$ values of combination treatment to individual treatments: $\mathrm{CI}=\left(\mathrm{TDT}_{\mathrm{B}}\right.$ combination of $\mathrm{TPL}$ and $\mathrm{ATF}) /\left(\mathrm{TDT}_{\mathrm{B}} \mathrm{TPL}\right.$ alone $+\mathrm{TDT}_{\mathrm{B}} \mathrm{ATF}$ alone $)$.

\section{Statistical analysis}

Statistical analysis was carried out using the SPSS software (version 11.0; SPSS, Chicago, IL). Data were expressed as the mean \pm standard deviations (SD) and analyzed by one-way ANOVA and the least significant difference tests. $P<0.05$ was considered statistically significant.

\section{Competing interests}

The authors declare that they have no competing interests. 


\section{Authors' contributions}

$\mathrm{ZCH}$ and $\mathrm{HZ}$ designed the study; $\mathrm{YL}, \mathrm{NP}$ and $J \mathrm{~L}$ performed experiments; $\mathrm{YL}$ and $\mathrm{HZ}$ analyzed data; $\mathrm{HZ}$ and $\mathrm{ZCH}$ wrote the paper. All authors read and approved the final manuscript.

\section{Acknowledgement}

The authors are grateful to grants from the Ministry of Science and Technology (2012CB967004, 2012AA020304, 2008BAI51B01 and 2012ZX09401012), the Chinese National Natural Sciences Foundation (81121062, 31200572 and 31071196), the Jiangsu Provincial Nature Science Foundation (BK2011228, BK2011573, BK2011048 and BZ2012050), the Bureau of Science and Technology of Changzhou, Jiangsu, China (CZ20110028, CZ20120004 and CM20122003).

\section{Author details}

${ }^{1}$ The State Key Laboratory of Pharmaceutical Biotechnology, College of Life Science, Nanjing University, 22 Han Kou Road, Nanjing 210093, PR China.

${ }^{2}$ Changzhou High-Tech Research Institute of Nanjing University, Changzhou 213164, Jiangsu, PR China. ${ }^{3}$ Jiangsu TargetPharma Laboratories Inc., Changzhou 213164, Jiangsu, PR China.

Received: 21 February 2013 Accepted: 5 June 2013

Published: 8 June 2013

\section{References}

1. Foekens JA, Schmitt M, Van Putten WL, Peters HA, Bontenbal M, Janicke F, Klijn JG: Prognostic value of urokinase-type plasminogen activator in 671 primary breast cancer patients. Cancer Res 1992, 52:6101-6105.

2. Laufs S, Schumacher J, Allgayer H: Urokinase-receptor (u-PAR): an essential player in multiple games of cancer: a review on its role in tumour progression, invasion, metastasis, proliferation/dormancy, clinical outcome and minimal residual disease. Cell Cycle 2006, 5:1760-1771.

3. Choong PF, Nadesapillai AP: Urokinase plasminogen activator system: a multifunctional role in tumour progression and metastasis. Clin Orthop Relat Res 2003(415):S46-S58.

4. Reuning U, Magdolen V, Wilhelm O, Fischer K, Lutz V, Graeff H, Schmitt M: Multifunctional potential of the plasminogen activation system in tumour invasion and metastasis (review). Int J Oncol 1998, 13:893-906.

5. Dano K, Andreasen PA, Grondahl-Hansen J, Kristensen P, Nielsen LS, Skriver $\mathrm{L}$ : Plasminogen activators, tissue degradation, and cancer. Adv Cancer Res 1985, 44:139-266

6. Andreasen PA, Egelund $\mathrm{R}$, Petersen $\mathrm{HH}$ : The plasminogen activation system in tumour growth, invasion, and metastasis. Cell Mol Life Sci 2000, 57:25-40.

7. Liu D, Aguirre GJ, Estrada Y, Ossowski L: EGFR is a transducer of the urokinase receptor initiated signal that is required for in vivo growth of a human carcinoma. Cancer Cell 2002, 1:445-457.

8. Wei Y, Lukashev M, Simon DI, Bodary SC, Rosenberg S, Doyle MV, Chapman HA: Regulation of integrin function by the urokinase receptor. Science 1996, 273:1551-1555.

9. Mars WM, Jo M, Gonias SL: Activation of hepatocyte growth factor by urokinase-type plasminogen activator is ionic strength-dependent. Biochem J 2005, 390:311-315

10. Koolwijk P, Van Erck MG, De Vree WJ, Vermeer MA, Weich HA, Hanemaaijer $\mathrm{R}$, Van HV: Cooperative effect of TNFalpha, bFGF, and VEGF on the formation of tubular structures of human microvascular endothelial cells in a fibrin matrix. Role of urokinase activity. J Cell Biol 1996, 132:1177-1188.

11. Rabbani SA, Gladu J: Urokinase receptor antibody can reduce tumour volume and detect the presence of occult tumour metastases in vivo. Cancer Res 2002, 62:2390-2397.

12. Kobayashi H, Gotoh J, Shinohara H, Moniwa N, Terao T: Inhibition of the metastasis of Lewis lung carcinoma by antibody against urokinase-type plasminogen activator in the experimental and spontaneous metastasis model. Thromb Haemost 1994, 71:474-480.

13. Li H, Soria C, Griscelli F, Opolon P, Soria J, Yeh P, Legrand C, Vannier JP, Belin D, Perricaudet M, Lu H: Amino-terminal fragment of urokinase inhibits tumour cell invasion in vitro and in vivo: respective contribution of the urokinase plasminogen activator receptor-dependent or independent pathway. Hum Gene Ther 2005, 16:1157-1167.
14. Li H, Griscelli F, Lindenmeyer F, Opolon P, Sun LQ, Connault E, Soria J, Soria C, Perricaudet M, Yeh P, Lu H: Systemic delivery of antiangiogenic adenovirus AdmATF induces liver resistance to metastasis and prolongs survival of mice. Hum Gene Ther 1999, 10:3045-3053.

15. Mohanam S, Chandrasekar N, Yanamandra N, Khawar S, Mirza F, Dinh DH, Olivero WC, Rao JS: Modulation of invasive properties of human glioblastoma cells stably expressing amino-terminal fragment of urokinase-type plasminogen activator. Oncogene 2002, 21:7824-7830.

16. Tao X, Younger J, Fan FZ, Wang B, Lipsky PE: Benefit of an extract of Tripterygium Wilfordii Hook $F$ in patients with rheumatoid arthritis: a double-blind, placebo-controlled study. Arthritis Rheum 2002, 46:1735-1743.

17. Matta R, Wang X, Ge H, Ray W, Nelin LD, Liu Y: Triptolide induces antiinflammatory cellular responses. Am J Trans/ Res 2009, 1:267-282.

18. Chen BJ: Triptolide, a novel immunosuppressive and anti-inflammatory agent purified from a Chinese herb Tripterygium wilfordii Hook F. Leuk Lymphoma 2001, 42:253-265.

19. Jiang $X H$, Wong $B C$, Lin $M C$, Zhu GH, Kung HF, Jiang SH, Yang $D$, Lam SK: Functional p53 is required for triptolide-induced apoptosis and AP-1 and nuclear factor-kappaB activation in gastric cancer cells. Oncogene 2001, 20:8009-8018.

20. Kupchan SM, Court WA, Dailey RG Jr, Gilmore CJ, Bryan RF: Triptolide and tripdiolide, novel antileukemic diterpenoid triepoxides from Tripterygium wilfordii. J Am Chem Soc 1972, 94:7194-7195.

21. Liu Q: Triptolide and its expanding multiple pharmacological functions. Int Immunopharmacol 2011, 11:377-383.

22. Tengchaisri T, Chawengkirttikul R, Rachaphaew N, Reutrakul V, Sangsuwan $R$ Sirisinha S: Antitumor activity of triptolide against cholangiocarcinoma growth in vitro and in hamsters. Cancer Lett 1998, 133:169-175.

23. Yang S, Chen J, Guo Z, Xu XM, Wang L, Pei XF, Yang J, Underhill CB, Zhang $\mathrm{L}$ : Triptolide inhibits the growth and metastasis of solid tumours. Mol Cancer Ther 2003, 2:65-72.

24. Tang XY, Zhu YQ, Tao WH, Wei B, Lin XL: Synergistic effect of triptolide combined with 5-fluorouracil on colon carcinoma. Postgrad Med J 2007, 83:338-343.

25. Xu B, Guo X, Mathew S, Armesilla AL, Cassidy J, Darling JL, Wang W: Triptolide simultaneously induces reactive oxygen species, inhibits NFkappaB activity and sensitizes 5-fluorouracil in colorectal cancer cell lines. Cancer Lett 2010, 291:200-208.

26. Westfall SD, Nilsson EE, Skinner MK: Role of triptolide as an adjunct chemotherapy for ovarian cancer. Chemotherapy 2008, 54:67-76.

27. Huynh PN, Hikim AP, Wang C, Stefonovic K, Lue YH, Leung A, Atienza V, Baravarian S, Reutrakul V, Swerdloff RS: Long-term effects of triptolide on spermatogenesis, epididymal sperm function, and fertility in male rats. J Androl 2000, 21:689-699.

28. Ye X, Li W, Yan Y, Mao C, Cai R, Xu H, Yang X: Effects of cytochrome P4503A inducer dexamethasone on the metabolism and toxicity of triptolide in rat. Toxicol Lett 2010, 192:212-220.

29. Fidler JM, Li K, Chung C, Wei K, Ross JA, Gao M, Rosen GD: PG490-88, a derivative of triptolide, causes tumour regression and sensitizes tumours to chemotherapy. Mol Cancer Ther 2003, 2:855-862.

30. Lee KY, Park JS, Jee YK, Rosen GD: Triptolide sensitizes lung cancer cells to TNF-related apoptosis-inducing ligand (TRAIL)-induced apoptosis by inhibition of NF-kappaB activation. Exp Mol Med 2002, 34:462-468.

31. Dan HC, Cooper MJ, Cogswell PC, Duncan JA, Ting JP, Baldwin AS: Aktdependent regulation of NF-\{kappa\}B is controlled by mTOR and Raptor in association with IKK. Genes Dev 2008, 22:1490-1500.

32. Rogers R, Ouellet G, Brown C, Moyer B, Rasoulpour T, Hixon M: Cross-talk between the Akt and NF-kappaB signalling pathways inhibits MEHPinduced germ cell apoptosis. Toxicol Sci 2008, 106:497-508.

33. Ouyang DY, Wang YY, Zheng YT: Activation of c-Jun N-terminal kinases by ribotoxic stresses. Cell Mol Immunol 2005, 2:419-425.

34. Dhanasekaran DN, Reddy EP: JNK signalling in apoptosis. Oncogene 2008 27:6245-6251

35. Blasi F, Carmeliet P: UPAR: a versatile signalling orchestrator. Nat Rev Mol Cell Biol 2002, 3:932-943.

36. Zhou H, Tang $Y$, Liang $X$, Yang $X$, Yang J, Zhu G, Zheng M, Zhang C: RNAi targeting urokinase-type plasminogen activator receptor inhibits metastasis and progression of oral squamous cell carcinoma in vivo. Int J Cancer 2009, 125:453-462.

37. Greenlee RT, Hill-Harmon MB, Murray T, Thun M: Cancer statistics, 2001. CA Cancer J Clin 2001, 51:15-36. 
38. Sohma I, Fujiwara Y, Sugita Y, Yoshioka A, Shirakawa M, Moon JH, Takiguchi S, Miyata H, Yamasaki M, Mori M, Doki Y: Parthenolide, an NF-kappaB inhibitor, suppresses tumour growth and enhances response to chemotherapy in gastric cancer. CANCER GENOMICS PROTEOMICS 2011, 8:39-47.

39. Friedberg JW, Vose JM, Kelly JL, Young F, Bernstein SH, Peterson D, Rich L, Blumel S, Proia NK, Liesveld J, Fisher RI, Armitage JO, Grant S, Leonard JP: The combination of bendamustine, bortezomib, and rituximab for patients with relapsed/refractory indolent and mantle cell non-Hodgkin lymphoma. Blood 2011, 117:2807-2812.

40. Duffy MJ: Proteases as prognostic markers in cancer. Clin Cancer Res 1996, 2:613-618.

41. Shimizu M, Cohen B, Goldvasser P, Berman H, Virtanen C, Reedijk M: Plasminogen activator UPA is a direct transcriptional target of the JAG1Notch receptor signalling pathway in breast cancer. Cancer Res 2011, 71:277-286.

42. Dear AE, Medcalf RL: The urokinase-type-plasminogen-activator receptor (CD87) is a pleiotropic molecule. Eur J Biochem 1998, 252:185-193.

43. Zhu F, Jia S, Xing G, Gao L, Zhang L, He F: cDNA transfection of aminoterminal fragment of urokinase efficiently inhibits cancer cell invasion and metastasis. DNA Cell Biol 2001, 20:297-305.

44. Li H, Lu H, Griscelli F, Opolon P, Sun LQ, Ragot T, Legrand Y, Belin D, Soria J, Soria C, Perricaudet M, Yeh P: Adenovirus-mediated delivery of a UPA/ UPAR antagonist suppresses angiogenesis-dependent tumour growth and dissemination in mice. Gene Ther 1998, 5:1105-1113.

45. Lue Y, Sinha Hikim AP, Wang C, Leung A, Baravarian S, Reutrakul V, Sangsawan R, Chaichana S, Swerdloff RS: Triptolide: a potential male contraceptive. J Androl 1998, 19:479-486.

46. Qiu D, Kao PN: Immunosuppressive and anti-inflammatory mechanisms of triptolide, the principal active diterpenoid from the Chinese medicinal herb Tripterygium wilfordii Hook. f. Drugs R\&D 2003, 4:1-18.

47. Liu Q, Chen T, Chen G, Shu X, Sun A, Ma P, Lu L, Cao X: Triptolide impairs dendritic cell migration by inhibiting CCR7 and COX-2 expression through PI3-K/Akt and NF-kappaB pathways. Mol Immunol 2007, 44:2686-2696.

48. Zhou B, Miao Z, Deng G, Ding J, Yang Y, Feng H, Li Y: Synthesis and biological evaluation of novel triptolide analogues for anticancer activity. Bioorg Med Chem Lett 2010, 20:6217-6221.

49. Shamon LA, Pezzuto JM, Graves JM, Mehta RR, Wangcharoentrakul S, Sangsuwan R, Chaichana S, Tuchinda P, Cleason P, Reutrakul V: Evaluation of the mutagenic, cytotoxic, and antitumor potential of triptolide, a highly oxygenated diterpene isolated from Tripterygium wilfordii. Cancer Lett 1997, 112:113-117.

50. Kitzen JJ, De Jonge MJ, Lamers CH, Eskens FA, Van Der BD, Van DL, Ter SJ, Brandely M, Puozzo C, Verweij J: Phase I dose-escalation study of F60008, a novel apoptosis inducer, in patients with advanced solid tumours. Eur J Cancer 2009, 45:1764-1772.

51. Lee KY, Chang W, Qiu D, Kao PN, Rosen GD: PG490 (triptolide) cooperates with tumour necrosis factor-alpha to induce apoptosis in tumour cells. J Biol Chem 1999, 274:13451-13455.

52. Chang WT, Kang JJ, Lee KY, Wei K, Anderson E, Gotmare S, Ross JA, Rosen GD: Triptolide and chemotherapy cooperate in tumour cell apoptosis. A role for the p53 pathway. J Biol Chem 2001, 276:2221-2227.

53. Yang $M$, Huang J, Pan $\mathrm{HZ}$, Jin J: Triptolide overcomes dexamethasone resistance and enhanced PS-341-induced apoptosis via PI3k/Akt/NFkappaB pathways in human multiple myeloma cells. Int J Mol Med 2008, 22:489-496.

54. Kang DW, Lee JY, Oh DH, Park SY, Woo TM, Kim MK, Park MH, Jang YH, Min DS: Triptolide-induced suppression of phospholipase D expression inhibits proliferation of MDA-MB-231 breast cancer cells. Exp Mol Med 2009, 41:678-685.

55. Li-Weber M: Targeting apoptosis pathways in cancer by Chinese medicine. Cancer Lett 2010, 332:304-312.

56. Papa S, Zazzeroni F, Pham CG, Bubici C, Franzoso G: Linking JNK signalling to NF-kappaB: a key to survival. J Cell Sci 2004, 117:5197-5208.

57. Chang L, Kamata H, Solinas G, Luo JL, Maeda S, Venuprasad K, Liu YC, Karin M: The E3 ubiquitin ligase itch couples JNK activation to TNFalphainduced cell death by inducing c-FLIP(L) turnover. Cell 2006, 124:601-613.

58. Freedman DA, Wu L, Levine AJ: Functions of the MDM2 oncoprotein. Cell Mol Life Sci 1999, 55:96-107.

59. Zhao F, Chen Y, Li R, Liu Y, Wen L, Zhang C: Triptolide alters histone H3K9 and H3K27 methylation state and induces G0/G1 arrest and caspase- dependent apoptosis in multiple myeloma in vitro. Toxicology 2010, 267:70-79.

60. Barre B, Perkins ND: A cell cycle regulatory network controlling NFkappaB subunit activity and function. EMBO J 2007, 26:4841-4855.

61. Phillips PA, Dudeja V, McCarroll JA, Borja-Cacho D, Dawra RK, Grizzle WE, Vickers SM, Saluja AK: Triptolide induces pancreatic cancer cell death via inhibition of heat shock protein 70. Cancer Res 2007, 67:9407-9416.

62. Zhang C, Cui GH, Liu F, Wu QL, Chen Y: Inhibitory effect of triptolide on lymph node metastasis in patients with non-Hodgkin lymphoma by regulating SDF-1/CXCR4 axis in vitro. Acta Pharmacol Sin 2006, 27:1438-1446

63. Chang HJ, Kim MH, Baek MK, Park JS, Chung IJ, Shin BA, Ahn BW, Jung YD: Triptolide inhibits tumour promoter-induced UPAR expression via blocking NF-kappaB signalling in human gastric AGS cells. Anticancer Res 2007, 27:3411-3417.

64. Carriero MV, Del VS, Franco P, Potena MI, Chiaradonna F, Botti G, Stoppelli MP, Salvatore M: Vitronectin binding to urokinase receptor in human breast cancer. Clin Cancer Res 1997 3:1299-1308

65. Kanse SM, Kost C, Wilhelm OG, Andreasen PA, Preissner KT: The urokinase receptor is a major vitronectin-binding protein on endothelial cells. Exp Cell Res 1996, 224:344-353.

66. Nykjaer A, Conese M, Christensen El, Olson D, Cremona O, Gliemann J, Blas F: Recycling of the urokinase receptor upon internalization of the UPA: serpin complexes. EMBO J 1997, 16:2610-2620.

67. Li Y, Knisely JM, Lu W, McCormick LM, Wang J, Henkin J, Schwartz AL, Bu G: Low density lipoprotein $(\mathrm{LDL})$ receptor-related protein $1 \mathrm{~B}$ impairs urokinase receptor regeneration on the cell surface and inhibits cell migration. J Biol Chem 2002, 277:42366-42371.

68. Zhu W, Ou Y, Li Y, Xiao R, Shu M, Zhou Y, Xie J, He S, Qiu P, Yan G: A smallmolecule triptolide suppresses angiogenesis and invasion of human anaplastic thyroid carcinoma cells via down-regulation of the nuclear factor-kappa B pathway. Mol Pharmacol 2009, 75:812-819.

69. Ossowski L, Guirre-Ghiso JA: Urokinase receptor and integrin partnership: coordination of signalling for cell adhesion, migration and growth. Curr Opin Cell Biol 2000, 12:613-620.

70. Yan C, Boyd DD: Regulation of matrix metalloproteinase gene expression. J Cell Physiol 2007, 211:19-26.

71. Li S, Dong W, Zong Y, Yin W, Jin G, Hu Q, Huang X, Jiang W, Hua ZC: Polyethylenimine-complexed plasmid particles targeting focal adhesion kinase function as melanoma tumour therapeutics. Mol Ther 2007, 15:515-523.

72. Chou TC: Theoretical basis, experimental design, and computerized simulation of synergism and antagonism in drug combination studies. Pharmacol Rev 2006, 58:621-681.

\section{doi:10.1186/1476-4598-12-54}

Cite this article as: Lin et al:: Herbal compound triptolide synergistically enhanced antitumor activity of amino-terminal fragment of urokinase. Molecular Cancer 2013 12:54.

\section{Submit your next manuscript to BioMed Central and take full advantage of:}

- Convenient online submission

- Thorough peer review

- No space constraints or color figure charges

- Immediate publication on acceptance

- Inclusion in PubMed, CAS, Scopus and Google Scholar

- Research which is freely available for redistribution

Submit your manuscript at www.biomedcentral.com/submit
C Biomed Central 